\title{
THE RELATIONSHIP BETWEEN PARASOCIAL THEORY AND BRAND PLACEMENT
}

\author{
Burcu ÖZBAY*
}

Received: 20.06.2019 - Accepted: 29.08.2019

Özbay, B. (2019). "The Relationship between Parasocial Theory and Brand Placement". Etkileşim. 4. 116-128.

\begin{abstract}
This paper reviews parasocial theory including parasocial interaction, parasocial relationship, parasocial break up, the death of a character or a celebrity, parasocial attachment and the correlation between brand placement and parasocial theory. This paper contains secondary sources, which is literature review. While brand placement has been a controversial issue since there are no exact rules to follow to make a successful brand placement and also it remains unclear whether brand placement is effective or not, the popularity of it has been growing rapidly. In spite of this, there are not many studies regarding the correlation between brand placement and parasocial theory. Therefore, the aim of this paper is to bring clarity to each subject matter and the correlation between them.
\end{abstract}

Keywords: parasocial theory, brand placement, fictional characters, celebrities. 


\title{
PARASOSYAL TEORI VE MARKA YERLEŞTIRME ARASINDAKI iLIŞKi
}

\author{
Burcu ÖZBAY*
}

Gönderim Tarihi: 20.06.2019 - Kabul Tarihi: 29.08.2019

Özbay, B. (2019). "The Relationship between Parasocial Theory and Brand Placement". Etkileşim. 4. 116-128.

\section{Özet}

Bu makale parasosyal etkileşim, parasosyal ilişki, parasosyal ayrılma, bir karakterin veya bir ünlünün ölümü, parasosyal ilişkisinin marka yerleşimi ile ilişkisini incelemektedir. Bu makale literatür taraması olan ikincil kaynakları içermektedir. Marka yerleştirme tartışmalı bir konudur ve bunun nedenlerinden biri başarılı bir marka yerleştirme yapmak için izlenecek kesin kuralların bulunmamasıdır. Popülerliği hızla artmasına rağmen marka yerleştirme konusunda ve özellikle parasosyal teori arasındaki korelasyon ile ilgili çok fazla çalışma yoktur. Bu nedenle, bu makalenin amacı yukarıda bahsi geçen konulara netlik kazandırmak ve literatür taramasına katkı sağlamaktır.

Anahtar Kelimeler: parasosyal teori, marka yerleştirme, kurgusal karakterler, ünlüler. 


\section{Introduction}

How can having a seemingly close connection with a fictional character or celebrity be defined? A "parasocial" connection is a one-sided attachment, from audience members towards characters or celebrities. It can be developed further and lead viewers to purchase brands or products that are utilized by their favorite celebrities or characters. Furthermore, viewers can feel parasocially attached to even "badly behaved characters" since they are aware of the fact they are fictional. In terms of brand placement, "badly behaved characters" and well-behaved characters can be filmed while utilizing the same brand or the same product in a television series.

\section{Parasocial Interaction and Parasocial Relationship}

According to Ballentine and Martin (2005), parasocial theory is about creating one-sided connection between audiences and the media tool. Bocarnea and Brown (2006: 309) agree with Ballentine and Martin (2005) and claim that the media mediates parasocial interaction. These include news programmes, dramas, serials, magazines, and the Internet. According to Horton and Wohl (1956), an audience member does not play an important role at parasocial relations as it is one-sided relationship which, a character leads the relationship, which is why an audience member cannot start a new relationship. Hartmann and Goldhoorn (2011: 1106) develop their argument in the following way: when an audience member is in the state of being exposed to media while a famous person makes an effort to make viewers feel like they are being addressed in a personal level by looking at the camera, viewers can consider this relationship with their characters as if characters were real and it would lead viewers to bond with characters in a deeper way. For Bocarnea and Brown (2007: 309), the term 'persona' can be referred to wide range of celebrities, who are non-fictional people such as member of the cast and singers or fictional characters. Bocarnea and Brown (2006: 309), claim that imaginary characters or non-imaginary people (i.e. celebrities), when having been in the public eye and subject to media mediation, become subjects for 'attachment' by the media-consuming public; this attachment is based on media mediation maintaining the character/celebrity presence in stories. In serial drama this will be the place of a character in a fictional story line. With a celebrity, who may also be in a serial drama, this will be a story about their actual life. The point Bocarnea and Brown (2006: 309) are making is that an audience member needs to see the character/celebrity as part of their own life-narrative and this is done via media mediation creating and maintaining parasocial interaction with viewers. According to Kim and Kim (2018: 268), despite the fact that viewers know that neither characters nor narratives are actual, they perceive the narrative and the characters like they are real on their minds.

It is worth discussing these interesting facts revealed by Hartmann (2016: 132). His main argument is that many studies make the mistake of assuming 
'parasocial interaction' and the term 'parasocial relationship' is the same, but they are two distinct and dissimilar notions. According to Schramm and Knoll (2015), agreeing with Hartmann (2016: 132), add one more point to their argument, which is their duration as it is key between them. To clarify, parasocial interaction represents an audience member's engagement with characters during the act of subjecting to media while parasocial relationship continue to exist even when viewers are no longer being subject to media (Schramm and Knoll, 2015). For Hartmann (2016: 131-132), in parasocial interaction, viewers feel like they are in a state of having connected with media characters, which is in contrast to reality, for example, a television presenter salutes by staring at the television camera to give viewers get the impression that they are addressing them in a personal way but this impression cannot be accurate as media characters address the masses. Hartmann (2016) argues in parasocial relationships, formed when characters/celebrities have been in the public eye for some time, possibly years, viewers/members of the public may feel an attachment and emotional closeness to them.

According to Avramova et al. (2017: 684), "during narrative processing readers engage in (unconscious) perceptual simulation of the objects, characters, and events depicted in the story -a process which gives rise to experiences that closely mirror those resulting from engaging with the real world". However, this refers to readers who absorb texts. The engagement process with television may be different, but this point is still valid because televisual viewing still elicits an emotional or empathic response. Though people may consciously be aware that the drama is not real, viewers may be unable to stop having an instinctive, unconscious reaction to what happens on screen, promotes a product in an overt way on social media platform such as YouTube.

\section{The Correlation between Parasocial Relationship and Well Being}

According to Bernhold and Metzger (2018: 8), parasocial relationship may be useful for elderly people to lessen their anxiety levels in the case of suffering from severe anxiety attachment while having good interpersonal communication or anxiety attachment in a lesser degree while being bad at interpersonal communication. However, according to Bernhold and Metzger (2018: 9) parasocial relationship may worsen the situation and may lead elderly people to be more depressed in the case of suffering from severe anxiety attachment while suffering bad parent-child relationship because they may make an attempt to fill their gap, which can be a heart-breaking indication, by creating parasocial relationship in a strong way with characters but they may end up feeling sadder.

In another major study, Hartmann (2016: 140) has found that although parasocial relationship can be beneficial for lonely viewers and make them feel content, the level and reasons of loneliness can have an impact on whether viewers can bond with characters in a deeper way or not. For instance, audi- 
ence, who are diagnosed with long-term loneliness because of communication problems, may have a difficulty to bond with characters but audience, who are diagnosed with long-term loneliness because of having a surge of social anxiety or in the state of being immobile, may have a strong parasocial relationship and fulfil their desire of being content with characters. The reason for that is they can eradicate irritating consequences of the long-lasting desire of having a sense of belonging to a certain extent (Hartmann, 2016: 140). On the other hand, Hartmann (2016:138) also points out that if viewers attach with characters with the utmost level, it can cause a danger because viewers may isolate themselves from their real friends and affect their interpersonal skills. Viewers can even be unrealistic and begin to hope for the same attachment from their favorite characters towards them. It can be suggested that this parasocial relationship has a number of serious drawbacks, which is why dosage of parasocial relationship is significant as while a normal dosage of parasocial attachment can be beneficial on viewers' contentedness, utmost level of parasocial relationship can be harmful for viewers.

Maltby et al. $(2005: 21,28)$ have conducted a research with a group sample of 229 males and females whose ages differ from 14 to 16 residing in the USA, 183 males and females whose ages differ from 18 to 30 residing in the USA and 289 males and females whose ages differ from 22 to 60 residing in the USA. They found out that when having an extreme parasocial relationship with famous people, which is a form of worship, is linked to being unsatisfied with their own appearance. This relationship is exclusive to female teenagers and is a form of worship for intense personal factors (Maltby et al. 2005: 18). Famous people including models who are very slim are being praised by the media channels just because they are very slim and young people are affected by the message of the media channels and it leads especially young people, who are concerned about their appearance, to envy slim famous people while making an attempt to have a body like these celebrities, end up being sick such as having an eating disorder. It can be assumed that gender and age play an important role on this case.

\section{Parasocial Break Up with Celebrities and Characters and the Death of a Celebrity or a Character}

Hartmann (2016: 131) goes as far to claim that some viewers regard celebrities as 'significant' people in their lives, expressing the same level of affection, as they would feel towards a close family member. There are some global examples that could give empirical input to Hartmann's (2016: 131) claim. According to Cohen (2004), an audience member, who realizes that his or her favorite characters are going to be terminated with their roles, reacts to the situation in an analogous way as how he or she would react when ending relationship with people who he or she knows in his or her real life. The level of reaction depends on the level of attachment, which audience feels for their 
favorite characters, but Cohen (2003:192) argues that when viewers face the aforementioned situation, the level of sorrow that they feel towards their characters is not as strong as losing their real friends or their partners. Cohen's finding (2004) suggests that both parasocial relationship and real life relationships have an analogous effect on people in the case of terminating relationships. When it comes to the gender difference in reaction to parasocial break up, Cohen (2003: 199), has conducted a survey with a sample group of 381 adult males and females and 82 teenagers and argues that despite the fact that females may bond with characters in a Parasocial way more strongly when comparing them with males, there seems to be no sign of gender difference in reaction when they hear that their characters are no longer going to be on the programme.

In contrast to Cohen's research (2003: 192), Cohen and Hoffner (2016: 645) take the loss of viewers' favorite celebrities and public figures into consideration. They argue that when a real person loses her or his life, such as Princess Diana or David Bowie, it affects human beings more than a fictitious character. They believe the level of pain when a celebrity death takes place is parallel to the feelings that people experience when they grieve someone they knew in their real lives. Cohen and Hoffner (2016: 645-646), argues that when Robin Williams took his own life away, people, who liked Robin Williams, used their social media accounts to spread awareness about topics which are related to the state of his mental and his physical health to find positive aspects that emerged from an unfavorable situation. They argue this can be a technique for people to accept their losses, ease their mind and deal with their pain. As very few people actually knew his personally or had met him in the flesh, why should so many people express so much public grief for a stranger? In a similar way, the death of Elvis Presley, Michael Jackson and George Michael caused a worldwide outpouring of grief from fans, much of it centering on their personal emotional experiences related to the artist and the perceived meaningfulness of the artists' behavior and creative output to the mourner. Building from this, it could be surmised that the intensity of parasocial links, and associated emotions, may be predicated by how much an audience member likes the public figure/character. This is a consideration among theorists dealing with the affective dimensions of parasocial interaction (PSI).

\section{Parasocial Relationship with Characters who are Portrayed as Badly or Well Behaved and its Effect on Brand Attitude}

According to Schramm and Knoll (2015), even a badly behaved character can help brand awareness and recall as long as the product that is placed suits the character. For Knoll et al. (2015), whether a character is portrayed as being good or a badly behaved and therefore likeable or dislikeable although it is possible for viewers to like unpleasant characters, it does not have an impact on the placed product in a direct way. This exemplar exists in a Turkish film 
called içerde where a character, who is called Mert, acts as a corrupt police, drives a Fiat car while a character who is called Yusuf Müdür acts as a good police chief drives a Fiat car as well. In addition, several questions remain unanswered with this example as it remains unclear whether it has an impact on brand attitude in a positive way or not. Dias et al. (2017) agree with Knoll et al. (2015) and argue that an audience member may even form parasocial relationship with bad characters, for instance, despite the fact that a character who is represented as a murderer in the drama Dexter, an audience member may even form parasocial relationship plausibly with this negative character because an audience member is aware of the fact that this character is a fictional character. Knoll et al. (2015) state that in the case of PSI, when the impact is affective (emotional), viewers engage more intensely with good behaved characters. Surprisingly, when it comes to the behavioral effects of PSI, viewers engage with good characters considerably less than bad characters. This would suggest that behavioral responses are more likely to be provoked by negative actions on the part of characters. On the other hand, when PSIs manifest in a cognitive sense, being a well or a badly behaved character does not have an impact on the rate with which people engage with characters. They concluded, "That affective PSI processes have an influence on brand attitudes". Verhellen et al. (2013:298) argue if a famous person who is known to be a specialist in some aspect of life promotes a product in a covert way, people tend to perceive it in more negative way than a famous specialist person promotes a product in an overt way in YouTube as the audience finds it deceptive and insincere.

\section{Parasocial Attachment/Communication and Retrospective Imaginative Involvement}

According to Stever (2013: 5), when it comes to Parasocial theory, scholars have a tendency to distinguish between parasocial interaction and parasocial relationship, but there is one more category, which is parasocial attachment that should be taken into consideration as well. According to Cole and Leets (1999), the degree of attachment plays an important role regarding creating attachment in a parasocial way, for example while viewers, who have signs of anxious ambivalent personality, score the highest when it comes to attachment, viewers, who have signs symptoms of avoidant personality, score the lowest. In the case of audience members, who are categorized as secures, they are in the middle, which means that they may create parasocial interaction. According to Hartmann (2008: 193), paracommunication can be created between an audience member and new media characters as long as an audience member considers them genuine and an audience member is conscious that characters are inaccessible. Slater et al. (2018: 333) argue that some platforms such as movies or books do not allow longer period to be connected with characters due to their short time period, which is why bonding with characters through parasocial relationship is not easy. Slater et al. (2018: 333) state when 
this aforementioned situation happens, retrospective imaginative involvement offers a better grasp of reaction of viewers to movies or books. Furthermore, in retrospective imaginative involvement, an audience member does not develop an imaginary relationship with characters as a close friend; they picture them beyond the narrative. To give an example, an audience member may think what circumstances would occur if the character behaved in a different way or a viewer could picture himself or herself as one of characters.

\section{Soap Operas and Parasocial Theory}

Due to the nature of soap operas, which is the duration of soap operas and the continuity of a narrative and traits of characters, audience connect with soap operas over a period of time (Durak-Batıgün and Büyükşahin-Sunal, 2017: 53). Akıncı and Çakır (2017: 210), in a survey of 406 respondents make some questionable conclusions. The main one is that sometimes soap operas represent lives that viewers would like to have and it can lead viewers to elaborate on them (Akıncı and Çakır, 2017: 224). However, their research does show the role of brands in the serial drama and how placement encourages viewers to know particular brands. Durak-Batıgün and Büyükşahin-Sunal (2017: 54) have studied the effects of mental health, marriage, socioeconomic level on the parasocial relationship between a group of 1232 Turkish married women and television series characters and found out that the level of parasocial attachment decreases when the level of education increases and another important factor in deciding the level of parasocial attachment is the financial situation, which means when the level of parasocial attachment decreases, the level of financial situation increases. The parasocial aspect seems, according to Akıncı and Çakır (2017: 224), is for key characters to show and tell about a brand. The assumption being that this will encourage awareness and interest among some viewers, and possible action to own a particular brand. However, overt placement and characters describing the features of a brand are not, according to Akıncı and Çakır's (2017: 225) research popular with viewers, which can lead viewers see this technique as 'pushing' and is not something they find attractive. Therefore, it may be suggested that based on Akıncı and Çakır, (2017: 225) that if viewers see a brand being overtly promoted, they regard this as advertising, as pushing and not something they prefer. Durak-Batıgün and Büyükşahin-Sunal (2017: 54) state that Turkish married women generally watch local soap operas instead of international soap operas due to cultural consonance; for instance, Turkish soap operas are collectivist, international soap operas are individualist.

According to Heider (1958), a fan imitates his or her cult figure and people have a tendency to be fond of familiar entities. It can be assumed Turkish women may lean towards Turkish Celebrities or characters more than foreign celebrities or characters since Turkish viewers can have common culture with their local famous people and characters and they are more relatable to Tur- 
kish viewers. Dias et al. $(2017: 128,130)$ have conducted a web-enabled survey with a group of 309 females and males whose ages differ from 18 and 56 residing in Portugal and find out that since product placement has usually been considered as a communication tool by viewers regarding in the case of television series, the relationship which is created parasocially, can still exist amid viewers and characters who are depicted as badly behaving people in other words, they can be still a part of product placement method successfully if viewers connect with bad characters parasocially and their perspectives of product placement in a general term are favorable.

\section{The Correlation between Parasocial Theory and Brand Placement}

Kim et al. (2019: 24,26) have conducted a web-based survey with a sample group of 344 females and males living in the USA and found out that the feeling of loneliness is perceived to be positively correlated with feeling satisfied by checking out the social accounts of famous people and gaining an understanding of private lives of their favorite famous people. According to Kim et al. (2019: 21), social presence can be seen a factor that boosts viewers' relationships, which is Parasocial, with their famous people and make it more pleasing experience for viewers. Ferchaud et al. (2018: 91) have done research by using the content analysis method with a sample group of 234 YouTube videos. Ferchaud et al. (2018: 90) state that celebrities can take advantage of technology and give viewers the feeling and impression of a mutual connection such as looking at the camera in a direct way. Ferchaud et al. (2018: 93) continue their argument in the following way; when influencers such as 'YouTubers' talk about their private life either in a positive way or in a negative way, it leads viewers to consider them genuine and can lead viewers to create Parasocial relationship with them. For Slater et al. (2018), not only can an audience develop relationship, which is parasocial with talk show moderators or commentators, but also an audience can have a parasocial relationship with imaginary characters or non-imaginary people.

Slater et al. (2018: 331) state that to boost the parasocial interaction, talk show moderators and commentators make an attempt to give the impression of an eye contact and feeling of being addressed in a personal level to viewers by glancing at the television camera.

According to Sun and Wu (2012: 144), having Parasocial relationship with famous athletes is perceived to have direct relationship with watching sports and being in need of stimulation. Furthermore, according to Sun and Wu (2012: 144) creating parasocial relationship with famous athletes can be an advantageous for markets as their fans have a tendency to purchase products that are relating to them as well.

According to Dibble and Rosaen (2011), there is a difference between parasocial interaction and paracommunication in terms of efforts from viewers' 
side because viewers need to make a substantial effort to be in a state of feeling that the interaction is reciprocal. According to Sokolova and Kefi (2019:6), both trustworthiness and parasocial interaction play an important role when it comes to making a purchase of a product that is promoted by an influencer via their social media accounts such as YouTube and Instagram. Parasocial interaction tends to carry more importance over people who fall under the category of $Z$ and $Y$ while trustworthiness carries more importance over elderly people and when young viewers consume influencers whose contents are about beauty, they do not have a tendency to consider those influencers friends; it is like a habit instead while elderly people have a tendency to consider those influencers friends. Surprisingly, Sokolova and Kefi (2019: 6) continue their argument in the following way; youngsters have a tendency to engage with influencers in a parasocial way and follow influencers whose contents are regarding beauty in a regular way provided that youngsters feel like of having similarities with influencers while considering those influencers beautiful is not an important factor. It can be assumed that having similarities with beauty influencers may have a more important impact on parasocial interaction while finding beauty influencers beautiful does not carry an important effect on parasocial interaction. For Lueck (2015), when viewers bond with famous people in a parasocial way, an audience member would like to be informed about life of her or his favorite famous person, that is why, this urge leads viewers to check out their social media accounts regularly and purchase brands or products that are worn or used by their favorite famous people. Hwang and Zhang (2018) have conducted a web-based survey on 389 Chinese people who check out influencers' social media accounts and found out that parasocial relationship with influencers have an impact on people's purchase decisions.

According to Brown (2015), there are four different type regarding viewers' connection with characters or famous people such as transportation, parasocial interaction, worshipping and identification.

\section{Conclusion}

Scholars have defined the term parasocial variously. While some scholars can use parasocial interaction and parasocial relationship interchangeably; some scholars deem that they are different notions. When it comes to parasocial theory, scholars and practitioners mention parasocial interaction or relationship most of the time, but there is one more category, which is called parasocial attachment. Another important point is that parasocial interaction and parasocial relationship can be achieved from both badly or well-behaved characters and both badly or good behaved characters are associated with the same brands or products in narratives in the case of brand placement. 


\section{References}

Akıncı, S. and Çakır, V. (2017). “Televizyon Dizilerinde Ürün Yerleştirme ve Sponsorluğun Sonuçları". Inif e-dergi. 2(2). 210-228.

Avramova, Y. R., De Pelsmacker, P., Dens, N. (2017). "Brand Placement in Text: The Short and Long-Term Effects of Placement Modality and Need for Cognition". International Journal of Advertising. 36(5). 682-704. doi:10.1080/026 50487.2017.1335041.

Ballantine, P. W. and Martin, B. A. S. (2005). "Forming Parasocial Relationships in Online Communities". Advances in Consumer Research. 32. 197.

Batıgün, A. D. and Sunal, A. B. (2017). "Tv Dizilerinde Yer Alan Karakterlerle Kurulan Parasosyal Etkileşim: Evlilik Doyumu, Psikolojik Belirtiler ve Bazı Sosyal-Demografik Değişkenler Açısından Değerlendirme". Türk Psikoloji Dergisi. 32(79). 52-62. http://www.turkpsikolojidergisi.com.

Bernhold, Q. S. and Metzger, M. (2018). "Older Adults' Parasocial Relationships with Favorite Television Characters and Depressive Symptoms". Health Communication. 1-12. doi:10.1080/10410236.2018.1548336.

Brown, W. J. (2015). "Examining Four Processes of Audience Involvement with Media Personae: Transportation, Parasocial Interaction, Identification, and Worship". Communication Theory. 25(3). 259-283. doi:10.1111/comt.12053.

Brown, W. J. and Bocarnea, M. (2007). "Celebrity-Persona Parasocial Interaction Scale". R. A. Reynolds, R. Woods, J. D. Baker (eds.) Handbook of Research on Electronic Surveys and Measurements. (309-312). London: Idea Group Reference.

Cohen, E. L. and Hoffner, C. (2016). "Finding Meaning in a Celebrity's Death: The Relationship Between Parasocial Attachment, Grief, and Sharing Educational Health Information Related to Robin Williams on Social Network Sites". Computers in Human Behaviour. 65. 643-650. doi:10.1016/j. chb.2016.06.042.

Cohen, J. (2003). "Parasocial Breakups: Measuring Individual Differences in Responses to the Dissolution of Parasocial Relationships". Mass Communication and Society. 6(2). 191-202. doi:10.1207/S15327825MCS0602_5.

(2004). "Parasocial Breakups from Favourite Television Characters: The Role of Attachment Styles and Relationship Intensity". Journal of Social and Personal Relationships. 21(2). 187-202. doi:10.1177/0265407504041374.

Cole, T. and Leets, L (199). "Attachment Styles and Intimate Television Viewing: Insecurely Forming Relationships in a Parasocial Way". Journal of Social and Personal Relationships. 16(4). 496-511.

Dias, J. A., Dias, J. G., Lages, C. (2017). "Can Negative Characters in Soap Operas Be Positive for Product Placement?". Journal of Business Research. 71. 125132. doi:10.1016/j.jbusres.2016.10.010. 
Dibble, J. L. and Rosaen, S. F. (2011). “Parasocial Interaction as More Than Friendship: Evidence for Parasocial Interactions with Disliked Media Figures". Journal of Media Psychology. 23(3). 122-132. doi:10.1027/18-64-1105/ a000044.

Ferchaud, A., Grzeslo, J., Orme, S., LaGroue, J. (2018). "Parasocial Attributes and YouTube Personalities: Exploring Content Trends Across the Most Subscribed YouTube Channels". Computers in Human Behavior. 80. 88-96. doi:10.1016/j.chb.2017.10.041.

Hartmann, T. (2008). "Parasocial Interactions and Paracommunication with New Media Characters". Elly A. Konijn, Sonja Utz, Martin Tanis, Susan B. Barnes (eds.) Mediated Interpersonal Communication. (177-199). Routledge Taylor \& Francis Group. https://doi.org/10.4324/9780203926864.

(2016). "Parasocial Interaction, Parasocial Relationships, and Well-Being". L. Reinecke and M. B. Oliver (eds.) In The Routledge Handbook of Media Use and Well-Being: International Perspectives on Theory and Research on Positive Media Effects. (131-144). London: Taylor and Francis Ltd.

Hartmann, T. and Goldhoorn, C. (2011). "Horton and Wohl Revisited: Exploring Viewers' Experience of Parasocial Interaction". Journal of Communication. 61(6). 1104-1121. doi:10.1111/j.1460-2466.2011.01595.x.

Heider, F. (1958). The Psychology of Interpersonal Relations. New Jersey: John Wiley \& Sons Inc.

Hwang, K., and Zhang, Q. (2018). "Influence of Parasocial Relationship Between Digital Celebrities and Their Followers on Followers' Purchase and Electronic Word-of-Mouth Intentions, and Persuasion Knowledge". Computers in Human Behavior. 87. 155-173. doi:10.1016/j.chb.2018.05.029.

Kim, J., Kim, J., Yang, H. (2019). "Loneliness and the Use of Social Media to Follow Celebrities: A Moderating Role of Social Presence". The Social Science Journal. 56(1). 21-29. doi:10.1016/j.soscij.2018.12.007.

Kim, S. S. and Kim, S. (2018). "Perceived Values of TV Drama, Audience Involvement, and Behavioral Intention in Film Tourism". Journal of Travel \& Tourism Marketing. 35(3). 259-272. doi:10.1080/10548408.2016.1245172.

Knoll, J., Schramm, H., Schallhorn, C., Wynistorf, S. (2015). “Good Guy vs. Bad Guy: The Influence of Parasocial Interactions with Media Characters on Brand Placement Effects". International Journal of Advertising. 34(5). 720-743. do i:10.1080/02650487.2015.1009350.

Lueck, J. A. (2015). "Friend-Zone with Benefits: The Parasocial Advertising of Kim Kardashian". Journal of Marketing Communications. 21(2). 91-109. doi:10.1 080/13527266.2012.726235.

Maltby, J., Giles, D. C., Barber, L., McCutcheon, L. E. (2005). “Intense-Personal Celebrity Worship and Body Image: Evidence of a Link Among Female Adolescents". British Journal of Health Psychology. 10(1). 17-32. doi:10.1348/135910704X15257. 
Schramm, H. and Knoll, J. (2015). "Modeling the Impact of Parasocial Interactions with Media Characters on Brand Placement Effects". Journal of Promotion Management. 21(5). 548-565. doi:10.1080/10496491.2015.1055038.

Slater, M. D., Ewoldsen, D. R., Woods, K. W. (2018). "Extending Conceptualization and Measurement of Narrative Engagement After-the-Fact: Parasocial Relationship and Retrospective Imaginative Involvement". Media Psychology. 21(3). 329-351. doi:10.1080/15213269.2017.1328313.

Sokolova, K. and Kefi, H. (2019). "Instagram and YouTube Bloggers Promote It, Why Should I Buy? How Credibility and Parasocial Interaction Influence Purchase Intentions". Journal of Retailing and Consumer Services. doi:10.1016/j.jretconser.2019.01.011.

Sun, T. and Wu, G. (2012). "Influence of Personality Traits on Parasocial Relationship with Sports Celebrities: A Hierarchical Approach: Personality Traits and Parasocial Relationship". Journal of Consumer Behaviour. 11(2). 136146. doi:10.1002/cb.1378.

Verhellen, Y., Dens, N., Pelsmacker, P. D. (2013). “Consumer Responses to Brands Placed in Youtube Movies: The Effect of Prominence and Endorser Expertise". Journal of Electronic Commerce Research. 14(4). 287-303. 